Człowiek chory i umierający. Możliwości wsparcia i formy pomocy, red. J. Stala, Kraków 2014, Wydawnictwo Naukowe UPJPII, s. 49-6o. http://dx.doi.org/10.15633/9788374384117.04

ks. Mariusz Kuźniar*

Uniwersytet Karola w Pradze, Czechy

\title{
PSYCHOFIZYCZNY I DUCHOWY WYMIAR CIERPIENIA LUDZKIEGO
}

Cierpienie jest uniwersalną rzeczywistością życia ludzkiego. Tworzy nie tylko treść osobistych doświadczeń człowieka, ale jest również przedmiotem rozważań intelektualnych prowadzonych z wielu perspektyw. Oprócz miłości jest ono najważniejszym motywem zarówno w literaturze jak i w sztuce. Zagadnienie bólu, cierpienia fizycznego, psychicznego i duchowego staje się rzeczywistością powszednią wielu sfer ludzkiej aktywności. Celem artykułu jest krótka refleksja przede wszystkim nad jego psychofizycznym oraz duchowym wymiarem.

\section{Psychofizyczny wymiar cierpienia}

Cierpienie jest nieodłącznym towarzyszem każdego ludzkiego istnienia, tworząc konstytutywną część całego i złożonego psychofizycznego procesu jego rozwoju oraz istnienia. Obszar ludzkiego cierpienia jest niezwykle rozległy, zróżnicowany i wielowymiarowy oraz ma różne formy i postacie. Rozróżniamy cierpienie fizyczne związane na przykład z doświadczeniem choroby, ograniczoności, procesem starzenia i śmierci. Mówimy również o cierpieniu psychicznym czy psychologicznym spowodowanym przez różne negatywne doświadczenia w interpersonalnych relacjach na przykład niewdzięczność, opuszczenie, zdrada, pogarda, odrzucenie,

* KS. MARIUSZ KUŹNIAR - kapłan Archidiecezji Praha, doktor nauk teologicznych w zakresie katechetyki, adiunkt przy katedrze nauk pastoralno-prawniczych na Wydziale Katolickiej Teologii Uniwersytetu Karola w Pradze, dyrektor narodowego referatu katechetycznego Konferencji Episkopatu Czech, sekretarz Komisji Wychowania Katolickiego Konferencji Episkopatu Czech, członek Europejskiej Ekipy Katechetycznej (EEC). 
grzech $^{1}$. Czasami te różne formy cierpienia nakładają się na siebie, przekształcając się w prawdziwe zło społeczne, jak ma to miejsce w przypadku klęsk żywiołowych, katastrof, epidemii, głodu czy wojny.

Encyklopedia Katolicka mówi o cierpieniu, jako o stałym komponencie ludzkiego życia, związanym z ograniczonością struktury bytowej człowieka. Następnie, jako o stanie psychicznym człowieka wywołanym bądź bólem fizycznym albo psychicznym. Ten może być spowodowany bądź dolegliwością organizmu (chorobą) czy też niemożliwością zrealizowania celu lub przeżyciem doznanej przykrości ${ }^{2}$. Cierpienie jest tym wszystkim, czego osoba doświadcza, jako przykre, niepożądane i bolesne. Ponieważ człowiek tworzy psychosomatyczną jedność odczuwa ból zarówno za pośrednictwem ciała, jak i psychiki. Niemniej jednak odseparowanie dolegliwości, cierpień cielesnych od duchowych jest często żmudnym i skomplikowanym procesem ${ }^{3}$. Chociaż cierpienie jest stałym elementem ludzkiej egzystencji, często jest też niespodzianym faktorem, jednakże nie jest rzeczywistością samoistną czy przypadkową. Cierpienie doświadczane przez człowieka ma konkretne przyczyny, dlatego ważnym się staje poznanie istoty cierpienia i zrozumienie jego roli. W tym celu należy analizować powody, przyczyny cierpienia.

Pisząc o przyczynach cierpienia należy pamiętać o dwóch kwestiach. Z jednej strony chodzi o poznanie tego, co doprowadziło do cierpienia a $z$ drugiej strony należy szukać powiązania cierpienia $\mathrm{z}$ kondycją człowieka ${ }^{4}$. Z punktu widzenia psychologii egzystencjalnej cierpienie jest konkretnym nieprzyjemnym doświadczeniem psychicznym i egzystencjalnym spowodowanym zdarzeniami losowymi, zaburzeniami osobowości, zachwianiem hierarchii wartości, pod wpływem, którego pojawia się często w człowieku poczucie bezsensu i bezsilności. Według klasyfikacji egzystencjalno-antropologicznej rozróżniamy cztery wymiary ludzkiego cierpienia ${ }^{5}$ :

1 Por. S. Głaz, E. Sroczyńska, Antropologiczny wymiar cierpienia i sensu ludzkiego życia w rozumieniu Victora Emila Frankla, w: Żyć etycznie - żyć etyką, red. R. Janusz, Kraków 2009, 131-152; H. Krzysteczko, Główne kierunki i działy psychologii, w: Psychologia dla teologów, red. J. Makselon, Kraków 1995, s. 9-35; A. Nelicki, „Metakliniczna” koncepcja osoby V.E. Frankla, w: Klasyczne i współczesne koncepcje osobowości, red. A. Gałdowa, Kraków 1999, 177-194; J. Trzópek, Człowiek w ujęciu logoterapii Viktora Frankla, w: Wprowadzenie do psychologii egzystencjalnej, red. M. Opoczyńska, Kraków 1999, s. 148-161; M. Opoczyńska, Człowiek wobec wartości, w: Wybrane zagadnienia psychologii osobowości, red. A. Gałdowa Kraków 1995, s. 169-186.

2 Por. Encyklopedia Katolicka, Lublin 1985, s. 467.

3 Por. M. Szabat, Uwagi o naturze bólu i cierpienia, w: $W$ drodze do brzegu życia, red. E. Krajewska-Kułak, C. Łukaszuk, J. Lewko, Białystok 2011, tom VIII, s. 55.

4 Por. J. Makselon, Psychologiczne aspekty cierpienia, „Sympozjum - Periodyk Naukowy” 4 (20oo) nr 2 (7), s. 72-82.

5 Por. A. Längle, Cierpienie - wyzwanie egzystencjalne. Rozumienie, postępowanie i radzenie sobie z cierpieniem z perspektywy analizy egzystencjalnej, w: Wobec cierpienia, red. R. Jaworski, A. Rusak, W. Simon, Płock 2004, s. 219-236. 
a) Wymiar somatyczny, gdzie cierpienie jest bólem fizycznym (zranienia, choroby, zaburzenia funkcjonowania, jak problemy ze snem czy migreny).

b) Wymiar psychologiczny, gdzie cierpienie jest powiązane ze stratą czegoś albo kogoś (uczucia typu: niepokój, ociężałość i napięcie, brak emocji, pustka i psychologiczny ból lub zranienie).

c) Wymiar duchowy (osobowy), gdzie źródłem cierpienia jest doświadczenie autoalienacji, niebycia sobą wywołaną absencją czegoś, co jest niezbędne do spełnionej realizacji istnienia (uczucia typu: poczucie braku bezpieczeństwa, nadużycie zaufania, rozpacz, brak relacji, niesprawiedliwość, wyrzuty sumienia, poczucie winy).

d) Wymiar dynamiczny, gdzie przyczyną cierpienia egzystencjalnego jest niezdolność orientacji w większym kontekście, w którym możemy zrozumieć nasze życie i nasze działania, sukcesy czy też bezsensowny los (uczucia typu: daremności, braku sensu życia).

Zdaniem A. Längle wszystkie istniejące rodzaje ludzkiego cierpienia można przydzielić do jednej z tych kategorii lub ich kombinacji. Jakość lub stopień cierpienia danej osoby są uwarunkowane wieloma różnymi czynnikami osobowościowymi i stopniem jego dojrzałości ${ }^{6}$. Cierpienie jest wprawdzie doświadczeniem złożonym, ale konstytutywnym i powszechnym dla każdego człowieka. W pewnym sensie możemy twierdzić, że jest koniecznością jego rozwoju. Cierpienie może mieć wpływ na rozwój wewnętrzny. Bez cierpienia nie ma korekty dążeń ludzkich i nie ma dążenia do doskonałości. Nie ma uczenia się i nie ma refleksji nad własnym postępowaniem.

Życie człowieka kształtowane jest przez wartości, które pomagają mu dojrzewać do pełni człowieczeństwa ${ }^{7}$. Do wartości człowiek dojrzewa i dorasta stopniowo. Od początku aż do końca swojej egzystencji człowiek żyje wśród wartości. Te absorbują jego percepcję, kształtują jego postawy, nadają kierunek jego dążeniom i czynom. Formują jego relacje interpersonalne, pozwalają mu oceniać postawy i uczynki innych ludzi. Wartości umożliwiają człowiekowi znaleźć sens życia ${ }^{8}$, kierować swoim życiem, wybierać to, co jest w nim ważne. Człowiek jest więc ze

6 Por. A. Längle, Cierpienie - wyzwanie egzystencjalne..., dz. cyt.

7 Por. K. Popielski, Wartości i ich znaczenie w życiu ludzi, w: Człowiek-wartości-sens. Studia z psychologii egzystencji:logoteoria i nooteoria, logoterapia i nooterapia, red. K. Popielski, Redakcja Lublin 1996, s. 6176; K. Popielski, Psychologia egzystencji. Wartości w życiu, Lublin 2009, s. 17-64; K. Popielski, Logoteoria i logoterapia w kontekście psychologii współczesnej, w: Człowiek-pytanie otwarte, red. K. Popielski, Lublin, 1987, s. $27-66$.

8 Por. K. Popielski, Poczucie sensu życia jako doświadczenie egzystencjalnie znaczace i potrzeba rozwojowa, w: Wychowanie Tom 2. Pojęcia. Procesy. Konteksty. Ku czemu wychowywać w nieprzejrzystym świecie, red. M. Dudzikowa, M. Czerepaniak-Walczak, Gdańsk 2007, s. 40-42; K. Popielski, Psychologia egzystencji. Wartości w życiu, Lublin 2009. 
swej istoty ukierunkowany na świat wartości. Dążenie ku wartościom pomaga mu pokonywać sytuacje kryzysowe. Droga, jaką człowiek wybiera w procesie pokonywania cierpienia, indukuje, jak głęboko przeżywa on swoje życie i rozwija się, jako osoba. Człowiek, który poznał sens życia, jako wyższej formy egzystencji, jest w stanie wznieść się ponad cierpienie i może budować relację z transcendencją. Droga ta jest długim i złożonym procesem a forma przeżywania cierpienia jest niepowtarzalnym doświadczeniem każdego człowieka. Proces ten, przeżywany w świadomy sposób, jest jednocześnie szansą na znalezienie sensu własnego cierpienia. Jest również konstytutywnym elementem godności i wyjątkowości człowieka w świecie przyrody, albowiem tylko człowiek ma możliwość poszukiwania odpowiedzi na znaczenie sensu cierpienia w swoim życiu'.

Ciekawe i głębokie uwagi na temat cierpienia znajdziemy u samego Viktora E. Frankla. Według niego człowiek dzięki cierpieniu (homo patiens) ma możliwość komunikowania się ze światem. Cierpienie jest więc uważane w logoterapii za sposób komunikacji międzyosobowej i tak naprawdę może mieć pozytywną wartość w procesie przemiany człowieka. Frankl mówi o cierpieniu, jako o życiowym egzaminie czy próbie, ponieważ sens cierpienia spoczywa w tym, w jaki sposób człowiek wyrównuje się z cierpieniem. Rzeczą naturalną jest to, że człowiek się buntuje przeciwko cierpieniu, które go dotyka. Niemniej jednak nadanie cierpieniu jakiegokolwiek celu jest kryterium jego akceptacji.

Człowiek cierpiący nie zawsze może wpływać na koleje swojego losu, ale ma możliwość zmiany swojego stosunku do cierpienia. Może je przemienić w ofiarę i dar. Cierpienie, które ma wartość ofiary, może być przyjęte i uznane za cierpienie sensowne. Cierpienie może być więc przydatną pomocą w jego wewnętrznym dojrzewaniu, w zdobywaniu wewnętrznej wolności, w nabywaniu empatii, która czyni go zdolnym do rozumienia innych ludzi. Zyskuje w ten sposób doświadczenie autotranscendencji. Daje mu to możliwość głębszej analizy fenomenu jego własnego cierpienia, właściwym ukierunkowaniu go, nadaniu mu sensu i prawdziwej wartości. Wytrzymałość człowieka cierpiącego może być wielka, jeśli jest świadomy cierpienia. Sens cierpienia musi być wyraźny i mieć wartość. Ma to miejsce wtedy, gdy człowiek cierpiący zrealizuje sens poprzez autentyczne spełnienie swego losu. Ostateczny sens ludzkiego cierpienia jest $\mathrm{w}$ transcendencji ${ }^{10}$.

\footnotetext{
9 Por. Człowiek wobec bólu, cierpienia i śmierci, red. J. Stala, N. Bravena, Kraków 2013; Życie i śmierć. Wyzwania działalności charytatywnej, red. J. Stala, Tarnów 2012; Przestrzenie pracy socjalnej, red. J. Stala, Tarnów 2010.

${ }^{10}$ Por. K. Popielski, Logoteoria i logoterapia w kontekście psychologii współczesnej, w: Człowiek-pytanie otwarte, red. K. Popielski, Lublin 1987, s. 27-66; V. E. Frankl, Homo patiens, Warszawa 1984; V. E. Frankl, Wola sensu. Założenia i zastosowanie logoterapii, Warszawa 2010.
} 
Człowiek chcąc zachować zdrowie fizyczne i duchowe, potrzebuje głównie właściwego celu życia. Brak sensu życia może wieść człowieka do frustracji egzystencjalnej. Człowieka nie wypełnia jakiś uniwersalny czy abstrakcyjny sens, ale zawsze musi odnaleźć swój własny sens w konkretnej życiowej sytuacji. Sens jest uniwersalnym zjawiskiem, ponieważ każdy człowiek może go odnaleźć w jakimkolwiek momencie swojego życia ${ }^{11}$. Świadomość sensu życia, jego logicznego przeżywania jest jedną z głównych potrzeb człowieka. Doświadczenie sensu życia staje się fundamentem do dojrzałej radości i afirmacji życia. Ważnym aspektem realizowania sensu ludzkiego życia jest odkrycie celu życia oraz wolne i etycznie poprawne osobowe zaangażowanie człowieka. Człowiek nie może osiągnąć sensu życia jednorazowo raz na zawsze, ponieważ jest on związany z jego rozwojem. Nieustannie go poszukuje, ale i tworzy ${ }^{12}$. Jest związany z wysiłkiem (poszukiwanie, decyzje, trud, ryzyko i cierpienie). Doświadczenie przemijania ma zasadnicze znaczenie w zrozumieniu sensu życia. Dla człowieka poszukującego sensu życia jest ważne nie tylko zrozumienie rzeczywistości końca jego egzystencji, ale również właściwe nastawienie do cierpienia, ponieważ niejednokrotnie człowiek stojąc w obliczu cierpienia, własnego czy drugiej osoby, traci sens życia ${ }^{13}$. Ludzie doświadczający cierpienia potrzebują nie tylko pomocy przy leczenia bólu fizycznego, ale szeroko rozumianego wsparcia psychicznego i duchowego ${ }^{14}$. W dalszym punkcie artykułu będzie zgłębiany duchowy wymiar cierpienia, który ma swe religijne konotacje.

\section{Duchowy wymiar cierpienia}

Nie można ignorować faktu, że oprócz wielkiego dziedzictwa kulturowego i naukowego ludzkości, gdzie znajdziemy próby odpowiedzi dotyczących wielkich tematów ludzkiej egzystencji (sens życia, sens cierpienia, śmierć itd.), istnieje również ważne dla chrześcijan źródło poznania - Słowo skierowane do ludzkości, zawarte w Biblii. Boże słowo pomaga zgłębiać tajemnicę obecności zła w świecie.

\footnotetext{
${ }^{11}$ Por. K. Popielski, Logoteoria i logoterapia w kontekście psychologii współczesnej..., dz. cyt.

${ }^{12}$ Por. J. Stala, Osoba starsza a sens życia, w: Człowiek wobec bólu cierpienia i śmierci, red. J. Stala, N. Bravená, Kraków 2013, s. 23-33.

${ }^{13}$ Por. E. Osewska, Wartość życia i cierpienia osoby starszej w perspektywie pedagogiczno-teologicznej, w: Człowiek wobec bólu cierpienia i śmierci, red. J. Stala, N. Bravená, Kraków 2013, s. 11-21.

${ }^{14}$ Por. S. Głaz, E. Sroczyńska, Antropologiczny wymiar cierpienia i sensu ludzkiego życia w rozumieniu Victora Emila Frankla w: Żyć etycznie - żyć etyką, red. Red. R. Janusz, Kraków 2009, s. 131-152; M. Kuźniar, Nemoc, umírání, smrt jako pastorační výzva, w: Człowiek wobec bólu cierpienia i śmierci, red. J. Stala, N. Bravená, Kraków 2013, s. 49-55.
} 
Ukazuje, że cierpienie, które jest sensu stricto tajemnicą, jest często doświadczeniem bolesnym, ma, wbrew pozorom, również funkcję pedagogiczną. Wielkie biblijne tematy (Boża miłość, służba drugiemu człowiekowi, troska o ubogich, zło, grzech, cierpienie, odkupienie itd.) pomagają w znalezieniu odpowiedzi na egzystencjalne pytania, które nurtują każdego człowieka, bowiem każdy człowiek w pewnym momencie swojego życia staje w obliczu swojego cierpienia, czy też cierpienia innych ${ }^{15}$.

Starym Testament porusza temat cierpienia ukazując, że cierpienie jest karą za grzech pierworodny. Człowiek będący w raju, będący w całkowitej i intymnej łączności z Bogiem nie odczuwał cierpienia, ani nie doznawał śmierci. Przykład Hioba ukazuje, że cierpienie w chrześcijańskiej koncepcji nie ma tylko i wyłącznie związku z grzechem, ponieważ cierpią także niewinni ludzie. Na podstawie historii narodu wybranego możemy poznać jego zbawcze znaczenie, gdzie cierpienie ma pedagogiczny charakter. Często jest interpretowane, jako próba wierności w relacji do Boga, jako droga oczyszczenia i dojrzewania, jako zadośćuczynienie za własne grzechy i grzechy narodu ${ }^{16}$.

Chrześcijańska koncepcja cierpienia jest ściśle związana z osobą Jezusa Chrystusa na krzyżu. Jest on symbolem nadziei, miłości i odkupienia. Cierpiący i umierający Chrystus nadaje ludzkiemu cierpieniu nowy sens, którego autentycznym źródłem jest miłość, która nadaje odkupieniu i zbawieniu trwały i wieczny charakter dobra. On sam cierpiąc, jako Bóg i człowiek, stał się uczestnikiem ludzkich cierpień $^{17}$. Uzdrawia swoją miłosierną miłością najboleśniejsze zranienia ludzkiej natury ${ }^{18}$. Cierpienie może się więc stać środkiem prowadzającym do zbawienia, jeśli jest przez człowieka w odpowiedni sposób interpretowane i przyjmowane. Tak rozumiane cierpienie może mieć pedagogiczny wymiar, ponieważ może służyć Bogu do uszlachetnienia i uświęcenia człowieka. Człowiek, który cierpi, poprzez swoją ofiarę przyczynia się do uświęcenia nie tylko siebie samego, ale również bliźnich, a przede wszystkim tych, którzy jakkolwiek mu służą ${ }^{19}$.

Chrześcijaństwo mówi również o cierpieniu zastępczym, które zakłada, według wzoru Nauczyciela i Pana (zob. Jan 13, 1-15), przenoszenie nabytych przez

\footnotetext{
15 Por. S. Natoli, Dio? È un dilemma di tutti, „Jesus” 2 (2011), s. 95.

${ }^{16}$ Por. Cierpienie w ujęciu religioznawczym, w: Religia, Tom 3, red. T. Gadacz, B. Minerski, Warszawa 2002.

${ }_{17}$ Por. Salvifici doloris, 18-20.

${ }^{18}$ Por. Jan Paweł II, Zawierzam cały świat Bożemu miłosierdziu. Homilia podczas Mszy św. z okazji konsekracji świątyni Bożego Miłosierdzia, „L'Osservatore Romano“, wyd. Polskie 23 (2002) nr 9, s. 17.

${ }^{19}$ Por. Jan Paweł II, Wierzę w Kościót, Città del Vaticano 1996, s. 432.
} 
cierpienie zasług na korzyść innych ${ }^{20}$. Każdy chrześcijanin ma za zadanie kultywować subtelność serca i empatię pomagające nabyć trwałą postawę niesienia pomocy cierpiącemu człowiekowi (zob. Łk 10, 30-37). Dalszym aspektem ludzkiego cierpienia jest grzech. Cierpienie może być wywołane osobistym grzechem albo grzechem drugiego człowieka. Może mieć ono charakter winy oraz stanowić formę kary. Z perspektywy zbawczych czynów Chrystusa cierpienie może być dla człowieka jedyną szansą nawrócenia. Może się stać dla niego „darem niebios” i być błogosławieństwem ${ }^{21}$.

Papież Jan Paweł II podkreślał, że znaczenie cierpienia musimy rozpatrywać i zgłębiać kompleksowo tzn. w nadprzyrodzonej i ludzkiej perspektywie. Jest ono nadprzyrodzone, ponieważ jest zakorzenione w Boskiej tajemnicy odkupienia świata. Posiada również głęboko ludzką perspektywę, ponieważ w nim człowiek odkrywa samego siebie, swoje człowieczeństwo, swoją godność i swoje posłannictwo $^{22}$. W zgłębianiu tajemnicy ludzkiego cierpienia, jak również w procesie ukazania jego sensu, znaczenia i wartości dla ludzkiej egzystencji, może być użyteczna refleksja teologiczna, która interpretuje i kontekstualizuje zbawcze czyny zawarte w Biblii.

Połączenie ludzkiego doświadczenia, ludzkiej percepcji z darem wiary, z Objawieniem, może pomóc w głębszym zrozumieniu sensu cierpienia. Proponuję zatrzymać się przy czterech kwestiach związanych z problematyką cierpienia: cierpienie jest rzeczywistością powszechną (nieuniknioną) dla każdego człowieka; cierpienie nie jest karą za grzech, ale jego konsekwencją; cierpienie może prowadzić człowieka do pełni miłości; jakie postawy wobec cierpienia człowiek może przyjąć.

\section{a) Cierpienie jest nieuniknione}

Cierpienie, które jest wpisane w ludzką egzystencję jest nieuniknione, ale nie jest przekleństwem. Wprawdzie cały szereg zjawisk naturalnych, mających negatywny wpływ na życie ludzkie, jest niezależnych od ludzkiej wolności (trzęsienia ziemi, powodzie, choroby, nagłe zgony), niemniej jednak w wielu przypadkach są one spowodowane przez nieodpowiedzialność samego człowieka. Człowiek

${ }^{20}$ Por. K. Rahner, H. Vorgrimler, Mały słownik teologiczny, Warszawa 1987, k. 64; Salvifici doloris 17; A. Bartoszek, Głęboko ludzki i prawdziwie chrześcijański sens cierpienia, „Śląskie Studia Historyczno-Teologiczne" 32 (1999), s. 357-368.

${ }^{21}$ Por. A. Bartoszek, Głęboko ludzki i prawdziwie chrześcijański sens cierpienia, „Śląskie Studia Historyczno-Teologiczne" 32 (1999), s. 361-362; KKK 1501; Salvifici doloris, 23.

${ }^{22}$ Por. Salvifici doloris, 31. 
niestety nie dostrzega bogactwa i znaczenia naturalnego środowiska w całej pełni, skupiając się jedynie na tych, które służą celom doraźnego użycia i zużycia ${ }^{23}$.

Całe dzieło stworzenia, w tym życie ludzkie, jest wprawdzie wspaniałym Bożym darem, przejawem jego miłości (por. Rdz 1, 31), jednak nie posiada wartości nieskończonej. Bóg nieustannie wszechświat stwarza, podtrzymując jego istnienie (conservatio est continua creatio) ${ }^{24}$. Stworzenie jest więc ze swej natury niepełne i odnawia się dzień po dniu ${ }^{25}$. Cały wszechświat i człowiek są przeznaczeni do chwały, która ma się objawić ${ }^{26}$. Jęki i bóle natury można porównać z bólami nowego rodzącego się życia. Cierpienia ludzkości, katastrofy naturalne, klęski żywiołowe, choroby, czy śmierć, nie muszą więc być interpretowane jako przekleństwo, ale są koniecznością aktu stworzenia. Mogą one być potwierdzeniem tego, że dzieło stworzenia nie jest doskonałe, nie jest jeszcze kompletne. Jest ono ciągłym procesem, nieustannie się realizuje, aż do swej pełni (por. Rz 8, 19-23), poprzez tajemnicze odnowienie świata i człowieka - „nowe niebiosa i nową ziemię" (por. $2 \mathrm{P} 3,13)^{27}$. Dzieło stworzenia doświadcza granic swojej skończoności, wyrazem, której są ból i cierpienie. Zmierza ono do pełni życia w Bogu, po którym tęskni i dla którego jest przeznaczone. Życie doczesne jest więc tylko jednym etapem wędrówki ludzkości i wszechświata w kierunku pełnej realizacji w Bogu.

\section{b) Cierpienie nie jest karą}

W Starym Testamencie, szczególnie w powszechnej mentalności narodu wybranego powodzenie i życiowy sukces interpretowane były jako wyraz Bożego błogosławieństwa, natomiast każde niepowodzenie, cierpienie czy też nieszczęście były przejawem Bożego niezadowolenia, kary za grzechy. Niestety przekonanie to niejednokrotnie jest również aktualne w życiu współczesnego człowieka, również chrześcijan. Ewangelijne przesłanie ukazuje szerzej problem cierpienia (por. Łk 13, 1-5, J 9, 1-41). Jezus wyraźnie nie zgadza się z uproszczoną interpretacją wydarzeń i faktów. Doszukiwanie się winy w ofiarach wielu ludzkich tragedii nie jest właściwą postawą chrześcijanina. Jezus mówi o konieczności nawrócenia. Ponieważ jego brak, może spowodować nieobliczalne skutki, o wiele większe niż wspomniane tragedie. Fakt, że cierpienie nie jest karą, wynika również z samego faktu, że Jezus nie odmówił doświadczenia cierpienia i śmierci (por. Flp 2, 6-11),

\footnotetext{
${ }^{23}$ Por. Redemptor Hominis 15.

${ }^{24}$ Por. Jan Paweł II, Opatrzność Boża - afirmacja dzieła stworzenia, w: http://www.vatican.va/holy_father/ john_paul_ii/audiences/1986/documents/hf_jp-ii_aud_19860507_it.html (20.07.2014).

${ }^{25}$ Por. KKK 302.

${ }^{26}$ Por. KKK 293-294.

${ }^{27}$ Por. Gaudium et spes 37-39.
} 
pokazując, że zło nie jest karą, ale jest tak naprawdę niezbędnym krokiem w kierunku pełni życia w Bogu. Cierpienie i śmierć Chrystusa, nie są celem samym $\mathrm{w}$ sobie, ale nabywają pełny sens w świetle jego zmartwychwstania ${ }^{28}$. Można je zrozumieć tylko i wyłącznie w świetle Bożej miłości, która jest ostatecznym sensem wszystkiego, co na tym świecie istnieje ${ }^{29}$. Każde ludzkie cierpienie, zawiera w sobie obietnicę zbawienia. Fakt obecności zła w świecie, w różnych jego przejawach, jest zaproszeniem do obudzenia i pogłębienia miłości, która jest bezinteresownym darem a konkretnie przejawia się w służbie drugiemu człowiekowi nawiedzanemu przez cierpienie ${ }^{30}$.

\section{c) Cierpienie prowadzi do miłości}

Jedynie odniesienie do miłości pozwala wyjść poza tajemnicę bólu i cierpienia, i zrozumieć zbawczą moc Chrystusa ${ }^{31}$. Cierpienie i zło nie ma swojego źródła w Bogu, ponieważ on ze swej natury jest Dobrem najwyższym, ani też w człowieku, który został stworzony z miłości na Jego obraz i podobieństwo. Cierpienie i zło są naturalnymi konsekwencjami grzechu pierwszych rodziców ${ }^{32}$. Bóg zapowiada również, że grzech sprowadzi na świat zło (por. Rdz 3, 1-24). W rzeczywistości Bóg nie chce zła. Sam Jezus czynił dobro, dokonał wielu uzdrowień (por. Dz 10, 38). Cierpienie jest dla Chrystusa okazją do manifestowania Bożej miłości. Nieskończona Miłość zwalcza zło we wszystkich jego formach. Nie istnieje zło, którego Bóg by nie mógł przemienić w większe dobro. Cierpienie może człowieka przybliżyć do drogi prowadzącej do Boga ${ }^{33}$. Dlatego Bóg za pośrednictwem św. Pawła wzywa wszystkich chrześcijan, aby zło zwyciężali dobrem (por. Rdz 12, 21) i pomagali bezinteresownie znosić cierpienia bliźnim (por. Mt 25, 31-46). Jan Paweł II w liście apostolskim Salvifici doloris, komentując przypowieść o miłosiernym Samarytaninie (zob. Łk 10, 30-37), podkreślał, że cierpienie może prowadzić człowieka do miłości ${ }^{34}$.

\footnotetext{
${ }^{28}$ Por. Gaudium et spes 13 .

${ }^{29}$ Por. Salvifici doloris 18; Jan Paweł II, Pamięć i tożsamość. Rozmowy na przełomie tysiącleci, Kraków 2005.

${ }^{30}$ Por. Salvifici doloris 29.

${ }^{31}$ Por. Salvifici doloris 13.

${ }^{32}$ Por. KKK 416-417.

${ }^{33}$ Por. Jan Paweł II, Pamięć i tożsamość. Rozmowy na przełomie tysiącleci, Kraków 2005, s. 11-12.

${ }^{34}$ Por. Salvifici doloris 29.
} 


\section{d) Postawy wobec cierpienia}

Używając pewnego schematyzmu, można wyszczególnić, trzy zasadnicze postawy wobec $\mathrm{zła}^{35}$ :

- Pierwszy sposób, to jakakolwiek ucieczka od zła, ignorowanie zła.

- Drugi sposób, to próba przezwyciężania czy zwalczenia zła za pomocą zła, czy złych metod. Nieprzebaczenie również wpływa na powstanie nowego zła.

- Trzeci sposób, to droga wskazana przez Jezusa Chrystusa, droga podjęcia cierpienia, podjęcia skutków grzechu. Zdolność, gotowość i moc brania na siebie skutków zła, w łączności z Jezusem Chrystusem, w perspektywie Jego zmartwychwstania, stają się źródłem odkupienia. Właśnie taka postawa stanowi iście chrześcijańską odpowiedź na zło. Nie spoczywa ona tylko w zdolnościach naturalnych człowieka, ale opiera się o moc Jezusa Chrystusa (por. 2 Kor 4, 7-14).

\section{Zakończenie}

Cierpienie jest trwałym elementem ludzkiej egzystencji. Dla płodnego przeżywania cierpienia ważne jest bycie świadomym. W tym celu należy zgłębiać i uporządkować przeżyte bolesne doświadczenia, aby człowiek mógł pomagać innym zgłębiać tajemnicę cierpienia ${ }^{36}$. Ważne jest integralne spojrzenie na fenomen ludzkiego cierpienia (w wymiarze psychofizycznym i duchowym).

Chrześcijanin na podstawie doświadczenia wiary jest świadomy tego, że życie ziemskie jest naznaczone cierpieniem i jest konsekwencją grzechu pierworodnego. Chociaż cierpienie jest $z$ natury czymś złym, to jednak w konfrontacji ze złem życie staje się pełniejsze. Człowiek ma możliwość wewnętrznej konwersji. W łączności z Jezusem Chrystusem ma możliwość nadania cierpieniu nowego znaczenia. Dzięki zbawczej mocy Jezusa Chrystusa otrzymuje ono wymiar twórczy, zbawczy i pomaga człowiekowi dojrzewać do bycia nowym stworzeniem. Dzięki temu człowiek ma zdolność nowego spojrzenia na siebie, na drugiego człowieka, na świat i na obecność zła czy cierpienia w świecie.

\footnotetext{
${ }^{35}$ Por. Z. Kiernikowski, Rola cierpienia $w$ dopełnianiu się życia człowieka. Spojrzenie w świetle Biblii, w: Wobec cierpienia, red. R. Jaworski, A Rusak, W. Simon, Płock 2004, s. 11-38.

${ }^{36}$ Por. J. Stala, Osoba starsza a sens życia, w: Człowiek wobec bólu, cierpienia i śmierci, red. J. Stala, N. Bravena, Kraków 2013, s. 23-34; E. Osewska, Wartość życia i cierpienia osoby starszej w perspektywie pedagogiczno-teologicznej, w: Człowiek wobec bólu, cierpienia i śmierci, red. J. Stala, N. Bravena, Kraków 2013, s. 11-22.
} 


\section{Proponowana literatura}

Bartoszek A., Głęboko ludzki i prawdziwie chrześcijański sens cierpienia, „Śląskie Studia Historyczno-Teologiczne" 32 (1999), s. 357-368.

Człowiek wobec bólu, cierpienia i śmierci, red. J. Stala, N. Bravená, Kraków 2013.

Frankl V.E., Homo patiens, Warszawa 1984.

Frankl V.E., Wola sensu. Założenia i zastosowanie logoterapii, Warszawa 2010.

Głaz S., Sroczyńska E., Antropologiczny wymiar cierpienia i sensu ludzkiego życia w rozumieniu Victora Emila Frankla, w: Żyć etycznie - żyć etyka, red. R. Janusz, Kraków 2009, s. 131-152.

Jan Paweł II, Opatrzność Boża - afirmacja dzieła stworzenia, w: http://www.vatican.va/ holy_father/john_paul_ii/audiences/1986/documents/hf_jp-ii_aud_19860507_it.ht$\mathrm{ml}$ (20.07.2014).

Jan Paweł II, Pamięć i tożsamość. Rozmowy na przełomie tysiącleci, Kraków 2005.

Jan Paweł II, Wierzę w Kościót, Città del Vaticano 1996.

Jan Paweł II, Zawierzam cały świat Bożemu miłosierdziu. Homilia podczas Mszyśw. zokazji konsekracji świątyni Bożego Miłosierdzia, „L'Osservatore Romano”, wyd. Polskie, 23 (2002) nr 9, s. 17.

Kiernikowski Z., Rola cierpienia $w$ dopetnianiu się życia człowieka. Spojrzenie $w$ świetle Biblii, w: Wobec cierpienia, red. R. Jaworski, A Rusak, W. Simon, Płock 2004, s. 11-38.

Krzysteczko H., Główne kierunki i działy psychologii, w: Psychologia dla teologów, red. J. Makselon, Kraków 1995, s. 9-35.

Kuźniar M., Nemoc, umírání, smrt jako pastorační výzva, w: Człowiek wobec bólu cierpienia i śmierci, red. J. Stala, N. Bravená, Kraków 2013, s. 49-55.

Längle A., Cierpienie - wyzwanie egzystencjalne. Rozumienie, postępowanie i radzenie sobie z cierpieniem z perspektywy analizy egzystencjalnej, w: Wobec cierpienia, red. R. Jaworski, A. Rusak, W. Simon, Płock 2004, s. 219-236.

Makselon J., Psychologiczne aspekty cierpienia, „Sympozjum - Periodyk Naukowy” 4 (2000) $\mathrm{nr} 2$ (7), s. 71-83.

Natoli S., Dio? È un dilemma di tutti, „Jesus” 2 (2011), s. 95.

Nelicki A., „Metakliniczna” koncepcja osoby V. E. Frankla, w: Klasyczne i współczesne koncepcje osobowości, red. A. Gałdowa, Kraków 1999, s. 177-194.

Opoczyńska M., Człowiek wobec wartości, w: Wybrane zagadnienia psychologii osobowości, red. A. Gałdowa, Kraków 1995, s. 169-186.

Osewska E., Wartość życia i cierpienia osoby starszej w perspektywie pedagogiczno-teologicznej, w: Człowiek wobec bólu cierpienia i śmierci, red. J. Stala, N. Bravená, Kraków 2013, s. 11-21.

Popielski K., Logoteoria i logoterapia w kontekście psychologii współczesnej, w: Człowiek - pytanie otwarte, red. K. Popielski, Lublin, 1987, s. 27-66. 
Popielski K., Poczucie sensu życia jako doświadczenie egzystencjalnie znaczące i potrzeba rozwojowa, w: Wychowanie, Tom 2. Pojęcia. Procesy. Konteksty. Ku czemu wychowywać w nieprzejrzystym świecie, red. M. Dudzikowa, M. Czerepaniak-Walczak, Gdańsk 2007, s. 19 -52.

Popielski K., Psychologia egzystencji. Wartości w życiu, Lublin 2009.

Popielski K., Wartości i ich znaczenie w życiu ludzi, w: Człowiek-wartości-sens. Studia $z$ psychologii egzystencji: logoteoria i nooteoria, logoterapia i nooterapia, red. K. Popielski, Lublin 1996, s. 61-76.

Przestrzenie pracy socjalnej, red. J. Stala, Tarnów 2010.

Rahner K., Vorgrimler H., Mały słownik teologiczny, Warszawa 1987.

Stala J., Osoba starsza a sens życia, w: Człowiek wobec bólu cierpienia i śmierci, red. J. Stala, N. Bravená, Kraków 2013, s. 23-33.

Szabat M., Uwagi o naturze bólu i cierpienia, w: W drodze do brzegu życia, red. E. Krajewska-Kułak, C. Łukaszuk, J. Lewko, Białystok, 2011, tom VIII, 2011.

Tatar M., Duchowość cierpienia wobec wybranych ujęć psychologii, „Warszawskie Studia Pastoralne" 15 (2012), s. 133-16o.

Trzópek J., Człowiek w ujęciu logoterapii Viktora Frankla, w: Wprowadzenie do psychologii egzystencjalnej, red. M. Opoczyńska, Kraków 1999, s. 148-161.

Życie i śmierć. Wyzwania działalności charytatywnej, red. J. Stala, Tarnów 2012. 